\title{
SOME UNPUBLISHED LETTERS OF PAUL HAMILTON HAYNE
}

\author{
BY HERBERT F. SMITH
}

DR. SMiтh, formerly an assistant editor on the Journal and an assistant curator in the Special Collections of the Rutgers Library, is now on the staff of the Department of English, the University of Wisconsin.

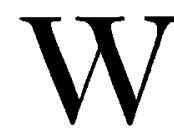

HEN Paul Hamilton Hayne's Collected Poems was reissued by D. Lothrop and Company, Charles Dunham Deshler wrote a short review for Harper's Monthly. ${ }^{1}$ Deshler was a nineteenth-century version of the Renaissance manbusinessman, author, critic, historian, and politician,- - but in none of these efforts was he successful enough to be remembered today. His modest drug business gave him enough income to support his literary and historical researches ${ }^{2}$ and his political activities, in which he was remarkably successful at favoring hopeless causes. ${ }^{3}$ He doubtless thought of himself as something of a patrician, and particularly in some of his critical writings a tone of condescension is apparent.

His review of Hayne's Collected Poems does not suffer from condescension, however. Less than three hundred words long, it is highly favorable; indeed, it is uncritical in both senses of that word. Full of combinations of adjectives and generalities, it was precisely the thing to please an author and convince all who read it that the reviewer had read the poems with "appreciation."

Hayne, as might be imagined, was well pleased with the review. Shortly after he read it, on May 20, I885, he wrote the editors of Harper's a note of thanks for their very generous and cordial estimate" of his work, adding, "may I not learn the name of my friendly

1 Unsigned review, LXXI, I56 (June, 1885 ).

2 His most important publications were Selections from the Poetry of Chaucer (New York and London, Wiley and Putnam, 1847); Afternoons with the Poets (New York, Harper and Brothers, 1879); and, among his historical writings, "A Glimpse of SeventySix," Harper's Monthly, XLIX (June-November, I 874 ).

3 His periods of greatest activity were the election of 1844 , when he backed the Whig Party and Henry Clay, and the election of 1856 , when he was National Secretary for the American or Know-Nothing Party. For the most complete analysis of Deshler's activities available, see Paul J. F. Hallerberg, "Charles D. Deshler, Versatile Jerseyman," unpublished Master of Arts thesis, Rutgers University, 1939. 
critic?" The editors must have co-operated, for Deshler wrote on May 25 a further testament of his appreciation to Hayne, and their correspondence, destined to be a short one because of Hayne's death the following year, began.

Hayne's first few letters to Deshler give prominent place to an offer Deshler made to facilitate the placing of Hayne's poems with Henry Mills Alden of Harper's. A letter of October 3 thanks Deshler for his offer "to speak to Mr. Alden about the Poem"; three days later Hayne wrote again to thank Deshler for his "prompt unselfish consideration" in bringing the same unidentified poem to Alden's attention. A letter written on November 6, I 885, asks Deshler to "notice" Hayne's "Savannah Sesquicentennial Ode," if he liked it. And one more letter, written January 7, I886, asks Deshler to remind Alden of his promise to publish the poem "Face to Face" in Harper's soon thereafter.

Although Deshler's usefulness as a contact within the Harper's organization was doubtless a primary motive for Hayne's early letters, each succeeding letter exhibits a growing friendliness that was obviously not dependent upon commercial motives. Hayne's last letter to Deshler, written only five months before his death is the culmination of their short but intense friendship. It is a summary, subjective but earnest, of his life particularly in relation to the effect of the Civil War upon him.

\section{"Copse Hill"}

My Dear Mr. Deshler:-

9th Feb. I 886.

How could I fail to be deeply touched by the tone of your last letter-? A tone so full of generous, manly sentiment, \& wise counsel besides? . . . .

Let me throw aside all conventionality for a moment, and open my heart to you; for verily, Instinct says that in you I have found a new friend;-one not disposed to judge harshly, or mistake for obtrusive Egöism the impulse now commanding me.

My "memories," you think "ought not to be gruesome ones?" Ah Heaven! if you only knew!!

4 This quotation and all following ones from letters by Hayne are from manuscript letters in the Charles D. Deshler Papers, MS. Ac. I 8, Rutgers University Library. Punctuation and spelling have been changed only when necessary for intelligibility. 
At the brightest period of my young manhood, came the war! It ruined thousands $\&$ tens of thousands, but few more completely than me $\&$ mine. The hopeful youth of ' 6 I - was a broken man in ' 65 ! From the summit of comfort and luxury I found myself thrown down to the level of sordid want.

Personally I could have laughed at fate; but to see a delicate \& aged Mother dying by inches;-to behold a noble wife forced to bend over the fire, cooking rancid bacon \& coarse homony [sic];to know that every minute of the day and night only unnaturally shortened the lives of both;-to be perfectly conscious not merely of the annihilation of every plan as to my own more extended Culture, by travel \&c, but of every plan for the culture of my only son,to glance round, \& miss the familiar forms of old beloved Comrades, carried off by Shot, or shell, or prison diseases-it was bitter, bitter, bitter!

If things amended somewhat, still I can almost recognize from my cottage window the grave of the good Mother, worn out by sorrow, \& privation, \& heart-break; - the thin face, and premature gray hair of my wife (uncomplaining as an angel) is ever before me,-and my boy, half educated, \& at great disadvantage consequently, can but struggle heavily on, with the enormous added difficulty of a feeble physical frame, chiefly the result of privation also,--of the lack of those blessings of change of air and judicious tendance (such as competence only can command), at certain critical epochs of his boyhood.

Add to these things, enforced labor for years; - the racked nerves, the worried brain, the deferred hope which makes the innermost spirit sick - the blasting stigma from once kindly friends, of having been a "Traitor \& Rebel," because I refused to desert my own People, \& turn my back upon the sepulchres of my fathers,--and finally such health, or want of it, that hardly one hour of any day was free from pain, \& heaviness; - consider I say all of these things; - and tell me, if you wonder that in the New Year Sonnet, \& elsewhere, there should be "an undercurrent of melancholy."_- Cultivate happiness," you gently and kindly say.

Alas, may I not inquire with Lucy Snowe, in that great novel "Villette" - "is Happiness indeed a plant to be placed in the mould \& tended with assiduous care?-" Rather is it not a glory, shining 
far down upon us out of heaven? - a divine dew which the soul upon certain of its summer mornings, feels dropping upon it, from the perennial bloom \& golden fruitage of Paradise?

But oh! my newly-found, \& valued Friend; do not mistake or picture me as a miserable old "Tribulation Trepid," a whining, peevish old "Cuss" (to adopt the Country patois) boring everybody with my misfortunes. Heaven forbid; - the first duty of a gentleman is to accept as calmly as may be, the Inevitable;-or should I not rather say, a Christian: if one in fact, can rightly or philosophically separate the terms; - Who was it? Dekker, I believe,-an Elizabethan Dramatist-in whose works we discover the following characterization of Christ;

"A tender patient, noble, suffering spirit

The first true Gentleman that ever breathed!"

The letter ends on a less serious note. Commenting on Deshler's job as reader for Harper's, Hayne remarked that Deshler would be tormented "by the stupidity of perhaps the majority of ambitious aspirants."

"Don't you think that to Io out of I 2 writers who may mail you their productions to be examined the following epigram would apply? -

Dried Tansy produces abortions, they say;

The theme is, of course uninviting-,

But oh! how much Tansy you take every day,

Before you sit down to your writing."

To summarize, Hayne's correspondence with Deshler depended somewhat on Deshler's ability and willingness to help him publish his poems. Apparently Hayne corresponded with many northern editors primarily for that purpose. ${ }^{5}$ Early in the correspondence, however, a rapport was established between the two men that went beyond such considerations. Hayne's last letter was written with a frankness that makes it a prime historical document; it is sufficient evidence of the effect of the Civil War on his work and personality.

${ }^{5}$ See Daniel Morley McKeithan, "A Correspondence Journal of Paul Hamilton Hayne," Georgia Historical Quarterly, XXVI, 249-272 (1942). See also letters of Hayne to Josiah Gilbert Holland, editor of Scribner's Monthly Magazine, Holland Papers, New York Public Library. Deshler is not mentioned by McKeithan. 